\title{
Post-retrieval late process contributes to persistence of reactivated fear memory
}

\author{
Daisuke Nakayama, Yoshiko Yamasaki, Norio Matsuki, and Hiroshi Nomura ${ }^{1}$ \\ Laboratory of Chemical Pharmacology, Graduate School of Pharmaceutical Sciences, The University of Tokyo, Bunkyo-ku, Tokyo \\ 113-0033, Japan
}

\begin{abstract}
Several studies have demonstrated the mechanisms involved in memory persistence after learning. However, little is known about memory persistence after retrieval. In this study, a protein synthesis inhibitor, anisomycin, was infused into the basolateral amygdala of mice $9.5 \mathrm{~h}$ after retrieval of contextual conditioned fear. Anisomycin attenuated fear memory after $7 \mathrm{~d}$, but not after $2 \mathrm{~d}$. In contrast, infusion of anisomycin 5- or 24-h post-retrieval was ineffective. These findings indicate that anisomycin attenuates the persistence of reactivated fear memory in a time-dependent manner. We propose that late protein synthesis is required for memory persistence after retrieval.
\end{abstract}

The process of memory formation is accompanied by protein synthesis, and various studies have demonstrated that the formation of long-term fear memory is disrupted by inhibiting protein synthesis around the time of learning or shortly afterward (Rosenblum et al. 1993; Bourtchouladze et al. 1998; McGaugh 2000; Johansen et al. 2011). During memory consolidation, protein synthesis is required to transform newly learned information, acquired during the acquisition phase, into stable modifications.

While the molecular mechanisms involved in the acquisition and consolidation phases have been extensively studied, little is known about memory persistence. Recent studies have shown that late protein synthesis after learning is required for memory persistence (Bekinschtein et al. 2007; Rossato et al. 2009), suggesting that consolidation-like events take place again. This was highlighted in one study by Bekinschtein et al. (2007), whereby infusion of the protein synthesis inhibitor anisomycin into the dorsal hippocampus $12 \mathrm{~h}$ after learning disrupted memory persistence, but not memory formation.

Several studies have shown that when a stabilized memory is retrieved, it can become labile again, and its maintenance requires additional protein synthesis (Nader et al. 2000; Debiec et al. 2002; Parsons et al. 2006a; Cai et al. 2012). Thus, this process is referred to as reconsolidation. Previous findings suggest that the reconsolidation phase involves many of the same core molecular features as the consolidation phase, including transcription factors (Kida et al. 2002), and de novo mRNA and protein synthesis (Nader et al. 2000; Debiec et al. 2002; Da Silva et al. 2008; Duvarci et al. 2008). However, no studies have explicated how memory persists after retrieval. It remains unclear whether persistence of retrieved memory requires a late protein synthesis-dependent phase as the persistence of original memory does. We aimed to clarify this in the present study.

To this end, we used contextual fear conditioning, employing footshock as our aversive stimulus. Our study focused on the basolateral amygdala (BLA), an area of the brain critical for the formation and maintenance of memory associated with fear (Phillips and LeDoux 1992; LeDoux 2000; Gale et al. 2004; Rudy et al. 2004; Poulos et al. 2009; Nomura et al. 2012). It has been shown that protein synthesis in the amygdala is necessary for the consolidation and reconsolidation of fear memory (Nader et al. 2000;

\footnotetext{
${ }^{1}$ Corresponding author

E-mail nomura@mol.f.u-tokyo.ac.jp

Article is online at http://www.learnmem.org/cgi/doi/10.1101/Im.029660.112.
}

Johansen et al. 2011). Anisomycin is a drug that has been widely utilized in various animal studies to explore the underlying molecular mechanisms involved in learning and memory (Rosenblum et al. 1993; Nader et al. 2000; Naghdi et al. 2003; Suzuki et al. 2004; Bekinschtein et al. 2007; Cai et al. 2012). Thus, in this study, we infused anisomycin into the BLA in order to investigate the role of protein synthesis in memory persistence after retrieval. Fear memory was measured on the day of testing (day 2), 2 d later (day 4), and 7 d later (day 9).

All experiments performed were approved by the animal experiment ethics committee at the University of Tokyo (approval number 19-37), and were in accordance with the University of Tokyo guidelines for the care and use of laboratory animals. Adult male C57BL/6J mice (Japan SLC Inc., Shizuoka, Japan), weighing 20-30 g and aged 8-13 wk, were housed 3-4 per cage, and kept on a 12-h light/dark cycle (lights on from 7 a.m. to 7 p.m.). They were given free access to food and water, and acclimated to daily handling for $1 \mathrm{wk}$ prior to the start of the study. Two days before the behavioral experiments were carried out, the animals were housed individually.

Mice were anesthetized with pentobarbital $(2.5 \mathrm{mg} / \mathrm{kg}$, i.p.) and xylazine (10 mg/kg, i.p.), and 26-gauge stainless-steel guide cannulas (Plastics One) were implanted in the BLA $(-1.4, \pm 3.5$, -2.7 relative to bregma). These cannulas were secured to the skull using a mixture of acrylic and dental cement, and 33-gauge dummy cannulas were then inserted into each guide cannula to prevent clogging. Mice were given at least $7 \mathrm{~d}$ of post-operative recovery time.

Anisomycin (Sigma) was dissolved in $\mathrm{HCl}$, diluted in phosphate-buffered saline (PBS), and adjusted to $\mathrm{pH} 7.4$ with $\mathrm{NaOH}$. Mice received intra-BLA infusion of anisomycin $(62.5 \mu \mathrm{g}, 0.5 \mu \mathrm{L} /$ side). Infusions were made over $4 \mathrm{~min}$, and the infusion cannulas were left in place for at least 2 min afterward in order to facilitate the diffusion of anisomycin throughout the whole BLA.

Contextual fear conditioning and subsequent testing were performed in a conditioning chamber $(18 \mathrm{~cm}$ wide, $15 \mathrm{~cm}$ deep, and $27 \mathrm{~cm}$ high) that had a stainless-steel grid floor (Kumakura et al. 2010). The chamber was cleaned with 70\% ethanol before each session. A conditioning session consisted of placing the animal in the chamber and delivering a 2 -sec footshock $(1 \mathrm{~mA})$ after $148 \mathrm{sec}$. The mice then received two additional shocks every $148 \mathrm{sec}$. They were kept in the chamber for an additional $60 \mathrm{sec}$ and were then returned to their home cages. The memory retrieval and testing sessions consisted of exposing the mice to the condi- 
tioning chamber for $5 \mathrm{~min}$ in the absence of a footshock. All sessions were performed between 8 a.m. and 11 a.m., and each session was video-recorded for automatic scoring of freezing, according to a previously described method (Nomura and Matsuki 2008). Fear memory was assessed and expressed as the percentage of time the animal remained frozen-a commonly used parameter for measuring conditioned fear in mice. Freezing was defined as the absence of all movements, except those related to breathing. All values were reported as mean \pm SEM. Repeated-measures ANOVA was used for multiple trial comparisons, and Student's $t$-test and paired $t$-test were performed to identify significant differences.

Mice were subjected to a conditioning session on day 1 and a retrieval session on day 2 (Fig. 1A). Anisomycin or vehicle (PBS) was infused into the BLA $9.5 \mathrm{~h}$ after the retrieval session (Fig. 1E). This interval between retrieval session and infusion was adopted because a previous study has demonstrated that brainderived neurotrophic factor (BDNF) is upregulated $\sim 10-12 \mathrm{~h}$ after learning (Ou et al. 2010). An ANOVA of freezing time comparing the drug treatment (anisomycin vs. vehicle) and session (day 2 vs. day 9) revealed a significant interaction $\left(F_{(1,15)}=9.4, P=0.0088\right)$ (Fig. 1C). Post hoc analysis revealed that there was no significant difference between the vehicle and treatment groups on day 2 $(P=0.88)$; however, compared to the vehicle group, the treatment group showed attenuated freezing behavior on day $9(P=$ 0.0033). Furthermore, the freezing time of animals infused with anisomycin was lower on day 9 than on day $2(P=0.0038)$. In contrast, the vehicle group showed no significant difference $(P=0.85)$, suggesting that the retrieval session on day 2 induced no extinction of conditioned fear. The anisomycin-induced decrease in freezing time was not observed when fear memory was tested on day $4\left(F_{(1,14)}=3.1, P=0.92\right)$ (Fig. $\left.1 \mathrm{~B}, \mathrm{D}, \mathrm{F}\right)$. These results indicate that the infusion of anisomycin into the BLA $9.5 \mathrm{~h}$ after retrieval interferes with the persistence of reactivated fear memory.

To determine whether there is a time window of sensitivity to anisomycin infusion following memory retrieval, anisomycin or vehicle was infused into the BLA 5 or $24 \mathrm{~h}$ after the retrieval session, and fear memory was tested $7 \mathrm{~d}$ later (Fig. 2A,B,G,H). An ANOVA demonstrated that there was no significant interaction between the treatments groups and session $\left(5 \mathrm{~h}, F_{(1,14)}=1.1\right.$, $\left.P=0.32 ; 24 \mathrm{~h}, F_{(1,14)}=0.30, P=0.59\right)$ (Fig. 2D,E), nor was there a significant difference between the groups infused at 5 and $24 \mathrm{~h}\left(5 \mathrm{~h}, F_{(1,14)}=0.20, P=0.66 ; F_{(1,14)}=0.0004, P=0.98\right)$. To test whether the attenuation of memory persistence is dependent upon memory retrieval, we performed the same experiment as in Figure $1 \mathrm{~A}$ in the absence of the retrieval session. Fear memory was then tested $7 \mathrm{~d}$ later (Fig. 2C,I). Mice infused with anisomycin showed intact fear memory $(P=0.63)$ (Fig. $2 \mathrm{~F})$. These data indicate that infusion of anisomycin into the BLA $9.5 \mathrm{~h}$ after retrieval attenuates fear memory persistence in a time- and retrievaldependent manner.

In the present study, we investigated the effect of anisomycin infusion into the BLA 5, 9.5, and $24 \mathrm{~h}$ after retrieval of a fear memory. Infusion of anisomycin $9.5 \mathrm{~h}$ after retrieval attenuated fear memory $7 \mathrm{~d}$ later. In contrast, the memory deficit was not observed $2 \mathrm{~d}$ later, indicating that anisomycin disrupts the persistence of reactivated fear memory in a time-dependent manner. Anisomycin infusion 5 and $24 \mathrm{~h}$ after memory retrieval had no significant effect on fear memory. These findings indicate that there is a time-specific window in which fear memory is sensitive to post-retrieval infusion of anisomycin, and that this late memory phase contributes to the persistence of reactivated fear memory.

It is widely accepted that protein synthesis around the time of memory retrieval, or shortly afterward, is required for postretrieval long-term memory. Previous studies have demonstrated that infusion of anisomycin around the time of retrieval disrupts memory $1 \mathrm{~d}$ later (Nader et al. 2000; Debiec et al. 2002). In contrast, we found that infusion of anisomycin $9.5 \mathrm{~h}$ after retrieval attenuates fear memory $7 \mathrm{~d}$ later, but not $2 \mathrm{~d}$ later. We also found that infusion of anisomycin 5 and $24 \mathrm{~h}$ after retrieval has no effect on fear memory. Taken together, these findings indicate that there are at least two distinct stabilizing processes involved in reactivated memory, and that the initial process contributes to the reconsolidation phase while the late process contributes to the persistence of reactivated memory.

Late-phase processing following memory retrieval may share some of the molecular mechanisms produced during memory acquisition, given that recent studies have found that late protein synthesis and BDNF signaling after learning are also involved in memory persistence (Bekinschtein et al. 2007; Ou et al. 2010). Both of these studies demonstrated that BDNF is upregulated in the rat hippocampus $10-12 \mathrm{~h}$ after acquisition of a one-time inhibitory avoidance training task, suggesting this is a critical
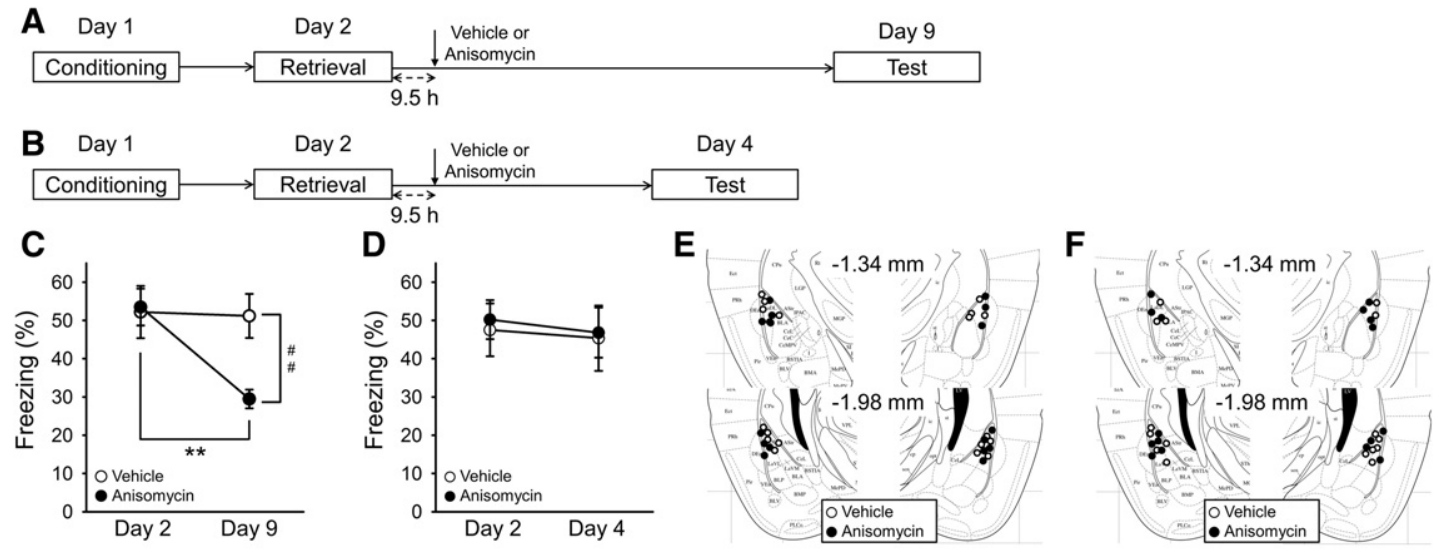

Figure 1. Infusion of anisomycin into the BLA $9.5 \mathrm{~h}$ after retrieval attenuates persistence of reactivated contextual fear memory. Mice received the vehicle or anisomycin $9.5 \mathrm{~h}$ after retrieval, and fear memory was reassessed on day $9(A)$. Compared with the vehicle group, the anisomycin group showed significant decreases in freezing on day $9(C) ;\left({ }^{* *}\right) P<0.01$, paired $t$-test; $\left({ }^{\# \#)} P<0.01\right.$, Student's $t$-test; vehicle, $n=8$ mice; anisomycin, $n=$ 9 mice. Mice received vehicle or anisomycin $9.5 \mathrm{~h}$ after retrieval, and fear memory was reassessed on day $4(B)$. Both groups showed comparable freezing on day $4(D)$ (vehicle, $n=8$ mice; anisomycin, $n=8$ mice). Histological verification of cannula placements for mice tested on day $9(E)$ and day $4(F)$. 


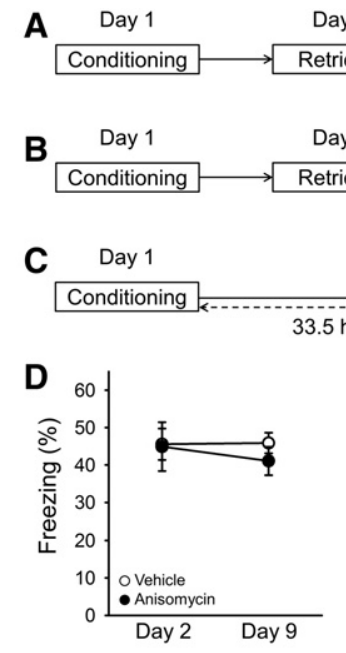

G
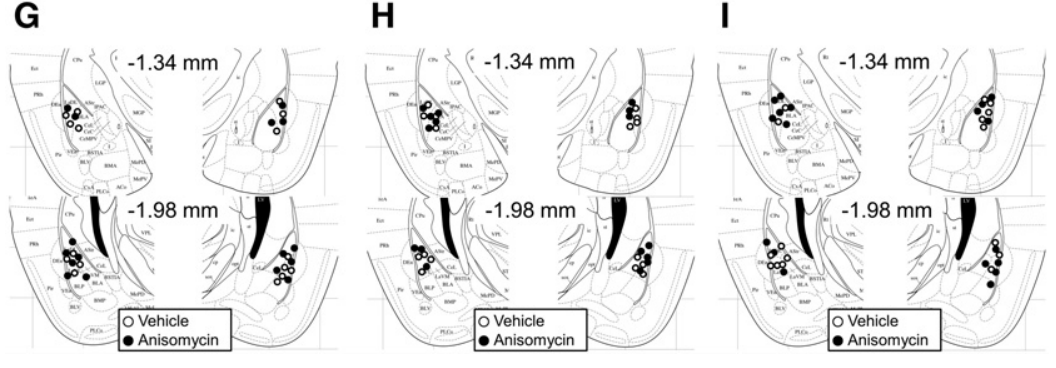

Figure 2. Attenuation of memory persistence is time- and retrieval-dependent. Mice received an infusion of vehicle or anisomycin into the BLA $5 \mathrm{~h}$ after retrieval, and fear memory was reassessed on day 9 $(A)$. Anisomycin infusion $5 \mathrm{~h}$ after retrieval had no effect on reactivated fear memory $(D)$ (vehicle, $n=8$ mice; anisomycin, $n=9$ mice). Mice received an infusion of vehicle or anisomycin into the BLA $24 \mathrm{~h}$ after retrieval, and fear memory was reassessed on day $9(B)$. Anisomycin infusion $24 \mathrm{~h}$ after retrieval had no effect on reactivated fear memory $(E)$ (vehicle, $n=8$ mice; anisomycin, $n=9$ mice). Mice received an infusion of vehicle or anisomycin without retrieval $33.5 \mathrm{~h}$ after conditioning, and fear memory was reassessed on day 9 (C). Anisomycin infusion without retrieval had no effect on reactivated fear memory $(F)$ (vehicle, $n=8$ mice; anisomycin, $n=9$ mice). Histological verification of cannula placements for mice receiving vehicle or anisomycin $5 \mathrm{~h}$ after retrieval $(G), 24 \mathrm{~h}$ after retrieval $(H)$, and without retrieval $(I)$.

process in memory persistence. They also reported that late-phase infusion of anisomycin and BDNF antisense oligonucleotide impaired the persistence of fear memory. Additionally, it has been shown that infusion of BDNF can rescue memory impairment induced by anisomycin (Martínez-Moreno et al. 2011).

Similar to our findings with reactivated memory, Bekinschtein et al. (2007) reported that late-phase infusion of anisomycin after a learning task disrupts memory $7 \mathrm{~d}$ later, but not $2 \mathrm{~d}$ later. It is thus possible that BDNF is upregulated $\sim 10 \mathrm{~h}$ after memory retrieval as well as after memory acquisition. If so, BDNF may be involved in the persistence of reactivated fear memory through synaptic stabilization. It has been reported that synaptic remodeling and structural changes accompany learning (Bailey et al. 2004; Lamprecht and LeDoux 2004; Segal 2005; Tanaka et al. 2008; Roberts et al. 2010; Caroni et al. 2012), and that inhibition of protein synthesis results in synapse destabilization (Bednarek and Caroni 2011). Given that reactivation of fear memory renders consolidated synapses labile (Kim et al. 2010), the proteins synthesized around $9.5 \mathrm{~h}$ after memory retrieval might contribute to the persistence of synaptic remodeling and structural plasticity.

In this study, we focused on the BLA because the BLA is an essential region for contextual fear conditioning (Kim and Fanselow 1992; Phillips and LeDoux 1992). More importantly, the protein synthesis in the BLA is necessary for initial stabilization of reactivated contextual fear memory (Mamiya et al. 2009). The hippo- campus has a pivotal interaction with the BLA for contextual fear memory (Canteras and Swanson 1992; Maren and Fanselow 1995; Seidenbecher et al. 2003) and is also important for stabilization of reactivated contextual fear memory (Debiec et al. 2002). Analyzing the interaction between the hippocampus and BLA 9-12 $\mathrm{h}$ after memory retrieval will help to understand a neural circuit mechanism underlying the memory persistence.

The dose and volume of anisomycin that we used has been widely used in many other studies (Nader et al. 2000; Schafe and LeDoux 2000; Parsons et al. 2006a, b; Wilensky et al. 2006). The concentration of anisomycin used here inhibits protein synthesis ranging from $50 \%$ to $80 \%$, with a plateau reached within $20 \mathrm{~min}$ after infusion and inhibition sustained for at least $3 \mathrm{~h}$ without lesion (Rosenblum et al. 1993; Parsons et al. 2006a). Because there are no studies reporting the diffusion or degradation of anisomycin, we cannot determine the precise time point critical for memory persistence. It is essential for future experiments to examine the diffusion or degradation of anisomycin. It is important to note that there is a controversial possibility that anisomycin has unintended effects, like inducing cell death (Rudy 2008). However, in this study, impairment of memory persistence by anisomycin was not due to damage in the BLA, since mice infused with anisomycin 5 or $24 \mathrm{~h}$ after memory retrieval showed intact memory. In addition to cell death, anisomycin has other side effects, like suppression of neural activity (Sharma et al. 2012), inducing gene expression (Radulovic and Tronson 2008), and inhibiting catecholamine synthesis (Flexner and Goodman 1975). These side effects make it difficult to conclude with confidence that the impairment of memory persistence by anisomycin was due to inhibition of late protein synthesis. However, taken together, our results indicate at the very least that there is a latephase process following memory retrieval, which is sensitive to anisomycin and critical for memory persistence, regardless of how anisomycin is acting.

In summary, the present study shows that late-phase infusion of anisomycin into the BLA after fear memory retrieval attenuates memory persistence in a time- and retrieval-dependent manner. Thus, we propose that late protein synthesis in the amygdala after retrieval is required for persistence of reactivated fear memory.

\section{Acknowledgments}

This work was supported by a Grant-in-Aid for Scientific Research (No. 23700367 to H.N., No. 23115101 to H.N.), Mochida Memorial Foundation for Medical and Pharmaceutical Research (to H.N.), SENSHIN Medical Research Foundation (to H.N.), The Research Foundation for Pharmaceutical Sciences (to H.N.) and Astellas Foundation for Research on Metabolic Disorders (to H.N.). 


\section{References}

Bailey CH, Kandel ER, Si K. 2004. The persistence of long-term memory: A molecular approach to self-sustaining changes in learning-induced synaptic growth. Neuron 44: 49-57.

Bednarek E, Caroni P. 2011. $\beta$-Adducin is required for stable assembly of new synapses and improved memory upon environmental enrichment. Neuron 69: 1132-1146.

Bekinschtein P, Cammarota M, Igaz LM, Bevilaqua LR, Izquierdo I, Medina JH. 2007. Persistence of long-term memory storage requires a late protein synthesis- and BDNF-dependent phase in the hippocampus. Neuron 53: 261-277.

Bourtchouladze R, Abel T, Berman N, Gordon R, Lapidus K, Kandel ER. 1998. Different training procedures recruit either one or two critical periods for contextual memory consolidation, each of which requires protein synthesis and PKA. Learn Mem 5: 365-374.

Cai D, Pearce K, Chen S, Glanzman DL. 2012. Reconsolidation of long-term memory in aplysia. Curr Biol 22: 1783-1788.

Canteras NS, Swanson LW. 1992. Projections of the ventral subiculum to the amygdala, septum, and hypothalamus: A PHAL anterograde tract-tracing study in the rat. J Comp Neurol 324: 180-194.

Caroni P, Donato F, Muller D. 2012. Structural plasticity upon learning: Regulation and functions. Nat Rev Neurosci 13: 478-490.

Da Silva WC, Bonini JS, Bevilaqua LR, Medina JH, Izquierdo I, Cammarota M. 2008. Inhibition of mRNA synthesis in the hippocampus impairs consolidation and reconsolidation of spatial memory. Hippocampus 18: 29-39.

Debiec J, LeDoux JE, Nader K. 2002. Cellular and systems reconsolidation in the hippocampus. Neuron 36: 527-538.

Duvarci S, Nader K, LeDoux JE. 2008. De novo mRNA synthesis is required for both consolidation and reconsolidation of fear memories in the amygdala. Learn Mem 15: 747-755.

Flexner LB, Goodman RH. 1975. Studies on memory: Inhibitors of protein synthesis also inhibit catecholamine synthesis. Proc Natl Acad Sci 72: 4660-4663.

Gale GD, Anagnostaras SG, Godsil BP, Mitchell S, Nozawa T, Sage JR, Wiltgen B, Fanselow MS. 2004. Role of the basolateral amygdala in the storage of fear memories across the adult lifetime of rats. J Neurosci 24: $3810-3815$.

Johansen JP, Cain CK, Ostroff LE, LeDoux JE. 2011. Molecular mechanisms of fear learning and memory. Cell 147: 509-524.

Kida S, Josselyn SA, Peña de Ortiz S, Kogan JH, Chevere I, Masushige S, Silva AJ. 2002. CREB required for the stability of new and reactivated fear memories. Nat Neurosci 5: 348-355.

Kim JJ, Fanselow MS. 1992. Modality-specific retrograde amnesia of fear. Science 256: 675-677.

Kim J, Song B, Hong I, Lee J, Park S, Eom JY, Lee CJ, Lee S, Choi S. 2010. Reactivation of fear memory renders consolidated amygdala synapses labile. J Neurosci 30: 9631-9640.

Kumakura K, Nomura H, Toyoda T, Hashikawa K, Noguchi T, Takeda K, Ichijo H, Tsunoda M, Funatsu T, Ikegami D, et al. 2010. Hyperactivity in novel environment with increased dopamine and impaired novelty preference in apoptosis signal-regulating kinase 1 (ASK1)-deficient mice. Neurosci Res 66: 313-320.

Lamprecht R, LeDoux J. 2004. Structural plasticity and memory. Nat Rev Neurosci 5: $45-54$.

LeDoux JE. 2000. Emotion circuits in the brain. Annu Rev Neurosci 23: $155-184$.

Mamiya N, Fukushima H, Suzuki A, Matsuyama Z, Homma S, Frankland PW, Kida S. 2009. Brain region-specific gene expression activation required for reconsolidation and extinction of contextual fear memory. J Neurosci 29: 402-413.

Maren S, Fanselow MS. 1995. Synaptic plasticity in the basolateral amygdala induced by hippocampal formation stimulation in vivo. J Neurosci 15: 7548-7564.

Martínez-Moreno A, Rodríguez-Durán LF, Escobar ML. 2011. Late protein synthesis-dependent phases in CTA long-term memory: BDNF requirement. Front Behav Neurosci 5: 61.

McGaugh JL. 2000. Memory—a century of consolidation. Science 287: $248-251$.
Nader K, Schafe GE, Le Doux JE. 2000. Fear memories require protein synthesis in the amygdala for reconsolidation after retrieval. Nature 406: $722-726$.

Naghdi N, Majlessi N, Bozorgmehr T. 2003. The effects of anisomycin (a protein synthesis inhibitor) on spatial learning and memory in CA1 region of rats hippocampus. Behav Brain Res 139: 69-73.

Nomura H, Matsuki N. 2008. Ethanol enhances reactivated fear memories. Neuropsychopharmacology 33: 2912-2921.

Nomura H, Nonaka A, Imamura N, Hashikawa K, Matsuki N. 2012. Memory coding in plastic neuronal subpopulations within the amygdala. Neuroimage 60: $153-161$.

Ou LC, Yeh SH, Gean PW. 2010. Late expression of brain-derived neurotrophic factor in the amygdala is required for persistence of fear memory. Neurobiol Learn Mem 93: 372-382.

Parsons RG, Gafford GM, Baruch DE, Riedner BA, Helmstetter FJ. 2006a. Long-term stability of fear memory depends on the synthesis of protein but not mRNA in the amygdala. Eur J Neurosci 23: $1853-1859$.

Parsons RG, Gafford GM, Helmstetter FJ. 2006b. Translational control via the mammalian target of rapamycin pathway is critical for the formation and stability of long-term fear memory in amygdala neurons. J Neurosci 26: 12977-12983.

Phillips RG, LeDoux JE. 1992. Differential contribution of amygdala and hippocampus to cued and contextual fear conditioning. Behav Neurosci 106: $274-285$.

Poulos AM, Li V, Sterlace SS, Tokushige F, Ponnusamy R, Fanselow MS. 2009. Persistence of fear memory across time requires the basolateral amygdala complex. Proc Natl Acad Sci 106: 11737-11741.

Radulovic J, Tronson NC. 2008. Protein synthesis inhibitors, gene superinduction and memory: Too little or too much protein? Neurobiol Learn Mem 89: 212-218.

Roberts TF, Tschida KA, Klein ME, Mooney R. 2010. Rapid spine stabilization and synaptic enhancement at the onset of behavioural learning. Nature 463: 948-952.

Rosenblum K, Meiri N, Dudai Y. 1993. Taste memory: The role of protein synthesis in gustatory cortex. Behav Neural Biol 59: 49-56.

Rossato JI, Bevilaqua LR, Izquierdo I, Medina JH, Cammarota M. 2009. Dopamine controls persistence of long-term memory storage. Science 325: $1017-1020$.

Rudy JW. 2008. Is there a baby in the bathwater? Maybe: Some methodological issues for the de novo protein synthesis hypothesis. Neurobiol Learn Mem 89: 219-224.

Rudy JW, Huff NC, Matus-Amat P. 2004. Understanding contextual fear conditioning: Insights from a two-process model. Neurosci Biobehav Rev 28: $675-685$.

Schafe GE, LeDoux JE. 2000. Memory consolidation of auditory pavlovian fear conditioning requires protein synthesis and protein kinase $A$ in the amygdala. J Neurosci 20: RC96.

Segal M. 2005. Dendritic spines and long-term plasticity. Nat Rev Neurosci 6: $277-284$.

Seidenbecher T, Laxmi TR, Stork O, Pape HC. 2003. Amygdalar and hippocampal $\theta$ rhythm synchronization during fear memory retrieval. Science 301: 846-850.

Sharma AV, Nargang FE, Dickson CT. 2012. Neurosilence: Profound suppression of neural activity following intracerebral administration of the protein synthesis inhibitor anisomycin. J Neurosci 32: $2377-2387$

Suzuki A, Josselyn SA, Frankland PW, Masushige S, Silva AJ, Kida S. 2004. Memory reconsolidation and extinction have distinct temporal and biochemical signatures. J Neurosci 24: 4787-4795.

Tanaka J, Horiike Y, Matsuzaki M, Miyazaki T, Ellis-Davies GC, Kasai H. 2008. Protein synthesis and neurotrophin-dependent structural plasticity of single dendritic spines. Science 319: $1683-1687$.

Wilensky AE, Schafe GE, Kristensen MP, LeDoux JE. 2006. Rethinking the fear circuit: The central nucleus of the amygdala is required for the acquisition, consolidation, and expression of Pavlovian fear conditioning. J Neurosci 26: 12387-12396.

Received November 17, 2012; accepted in revised form March 19, 2013. 


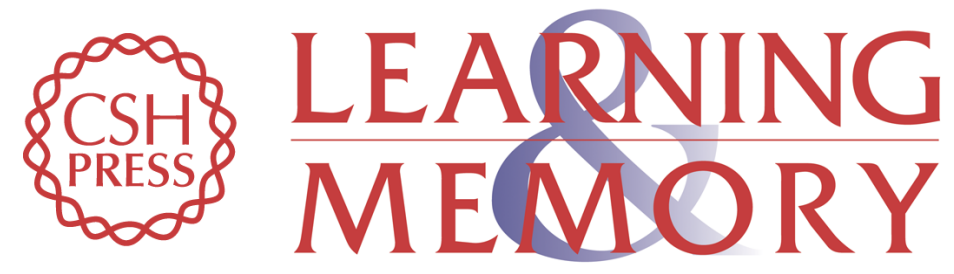

\section{Post-retrieval late process contributes to persistence of reactivated fear memory}

Daisuke Nakayama, Yoshiko Yamasaki, Norio Matsuki, et al.

Learn. Mem. 2013, 20:

Access the most recent version at doi:10.1101/Im.029660.112

References This article cites 45 articles, 18 of which can be accessed free at:

http://learnmem.cshlp.org/content/20/6/307.full.html\#ref-list-1

License

Email Alerting Receive free email alerts when new articles cite this article - sign up in the box at the Service top right corner of the article or click here. 